\title{
VARIA
}

\section{Ryszard Nowicki}

rnowicki@ukw.edu.pl

orcid.org/0000-0001-8507-2086

Uniwersytet Kazimierza Wielkiego w Bydgoszczy

Wydział Humanistyczny

ul. Jagiellońska 11

85-067 Bydgoszcz

\section{Księga inwentarzowa księgozbioru hrabiów Skórzewskich z Lubostronia - zachowana Inventory Book of the Skórzewski Counts' Lubostroń Library Collection - Preserved}

Summary: The palace library was established by count Fryderyk Skórzewski at Lubostron at the beginning of the $19^{\text {th }}$ century. Up to 1939, it was owned by the Skórzewski family representatives. In the 1920s, the valuable collection numbered approximately 20,000 volumes. However, the collection was not catalogued. This article proves that the preserved inventory book dates from the nineteenth century and concerns the library in Lubostroń. No information about the book is found in the source literature.

Keywords: Library, Skórzewski family, Lubostroń, Poland, $19^{\text {th }}$ century

Streszczenie: Bibliotekę pałacową w Lubostroniu na początku XIX w. założył Fryderyk hrabia Skórzewski. Do 1939 r. stanowiła własność przedstawicieli rodu Skórzewskich. W latach 20. XX w. wartościowy księgozbiór liczył ok. 20 tys. tomów. Zgromadzone materiały piśmiennicze nie były skatalogowane. $W$ artykule udowodniono, że zachowana księga inwentarzowa pochodzi z XIX w. i dotyczy biblioteki lubostrońskiej. Na temat jej istnienia nie znajdziemy żadnej informacji w literaturze przedmiotu.

Słowa kluczowe: biblioteka, Skórzewscy, Lubostroń, Polska, XIX wiek 
Do 1939 r. dwa księgozbiory: rodowy w Lubostroniu oraz ordynacki w Czerniejewie stanowiły własność IV ordynata na Radomicach-Czerniejewie Zygmunta hrabiego Skórzewskiego. Pierwszy z nich liczył pod koniec lat 20. XX w. ok. 20 tys. tomów ( $w$ tym ok. 30 inkunabułów), a drugi ok. 50 tys. tomów (w tym ok. 50 inkunabułów) ${ }^{1}$. Ordynat należał do największych w skali kraju prywatnych właścicieli zbiorów bibliotecznych. Posiadał wartościowe rękopisy, inkunabuły, stare druki, czasopisma, druki ulotne i okolicznościowe. Zasoby, gromadzone przez kilka pokoleń, służyły głównie rodzinie ${ }^{2}$. Poza zaledwie pojedynczymi przypadkami nie były dostępne dla osób z zewnątrz. Zygmunt Skórzewski miał świadomość znaczenia zgromadzonych wartościowych materiałów. W dwudziestoleciu międzywojennym ustanowił depozyt w Bibliotece Raczyńskich w Poznaniu. Zaczął przekazywać do instytucji założonej przez Edwarda Raczyńskiego najcenniejsze pozycje pochodzące z bibliotek lubostrońskiej i czerniejewskiej. Depozyt hrabiego należał do największych w Bibliotece. Ogółem w latach 1932-1938 przekazał ponad 6000 dzieł w ok. 11 tys. tomach i zeszytach ${ }^{3}$. Udostępnianie kolejnych materiałów zostało gwałtownie przerwane w wyniku wybuchu II wojny światowej.

Początek zbiorów lubostrońskich jest związany z księgozbiorem Marianny z Ciecierskich Skórzewskiej, żony gen. Franciszka Skórzewskiego, który w drugiej połowie XVIII w. liczył ok. 330 tytułów ${ }^{4}$. Pierwotnie książki zgromadzone przez

1 B. Szulc-Golska, Wielkopolskie biblioteki prywatne, w: S. Wierczyński (red.), Biblioteki wielkopolskie i pomorskie, Komitet Organizacyjny IV Zjazdu Bibliofilów i II Zjazdu Bibliotekarzy Polskich, Poznań 1929, s. 239, 250. Według Edwarda Chwalewika, biblioteka w Czerniejewie liczyła 20 tys. tomów, w tym ok. 400 inkunabułów (idem, Zbiory polskie, t. 1, Wydawnictwo J. Mortkowicza, Towarzystwo Wydawnicze w Warszawie, Warszawa 1926, s. 56). Autor wspomniał księgozbiór lubostroński, jednak bez podania danych liczbowych (ibidem, s. 364-365). Zob. także: B. Bieńkowska, W. Kowalski, H. Łaskarzewska, U. Paszkiewicz, S. Waligórski, Straty bibliotek w czasie Il wojny światowej w granicach Polski z 1945 roku. Wstępny raport o stanie wiedzy. Część I. Analiza, Część II. Tablice, Reklama Wojciech Wójcicki, Warszawa 1994, s. 169, 229; B. Bieńkowska (red.), Informator o stratach bibliotek i księgozbiorów domowych na terytoriach polskich okupowanych w latach 1939-1945 (bez Ziem Wschodnich), Ministerstwo Kultury i Dziedzictwa Narodowego, Poznań 2000, s. 76, 171.

2 B. Kosmanowa, Biblioteki polskie w Wielkim Księstwie Poznańskim, Wydawnictwo Naukowe Uniwersytetu im. Adama Mickiewicza, Poznań 1982, s. 55-57.

3 R. Nowicki, Fragment biblioteki rodowej i ordynackiej Skórzewskich w Bibliotece Raczyńskich, „Biblioteka" 2004, nr 8(17), s. 49-62. Zygmunt Skórzewski pierwszego roku, tj. od kwietnia do początków września 1932 r., z bibliotek czerniejewskiej i lubostrońskiej przekazał depozyt liczący ok. 6000 dzieł, w tym ok. 250 starych druków i kilka rękopisów. Do najcenniejszych XIX-wiecznych druków należały rzadkie katalogi księgarskie i antykwaryczne poznańskich księgarzy oraz Bogumiła Korna z Wrocławia. Do uporządkowania oraz skatalogowania dzieł Biblioteka Raczyńskich zaangażowała „osobną siłę bibliotekarską” (zob. A. Wojtkowski, „Habent sua fata...”. Jak rośnie i bogaci się Biblioteka Raczyńskich, „Kurier Poznański" 1932, R. 27, nr 410, s. 8).

4 Inventarium des Nachlass der 18 XI 1774 in Berlin verstorbenen Fr. Grafin von Skórzewska, Archiwum Państwowe Poznań, Akta majątkowe i rodzinne Skórzewskich - Lubostroń (dalej: APP L), sygn. 27, k. 137-168; R. Nowicki, Skórzewscy. Właściciele dóbr łabiszyńskich. Rola w życiu społeczno-politycznym wielkopolskiego ziemiaństwa, Wydawnictwo Adam Marszałek, Toruń 2002, s. 34; K. Kłudkiewicz, „Czarować chciała tylko 
Księga inwentarzowa księgozbioru hrabiów Skórzewskich... Inventory Book of the Skórzewski Counts' Lubostroń Library...

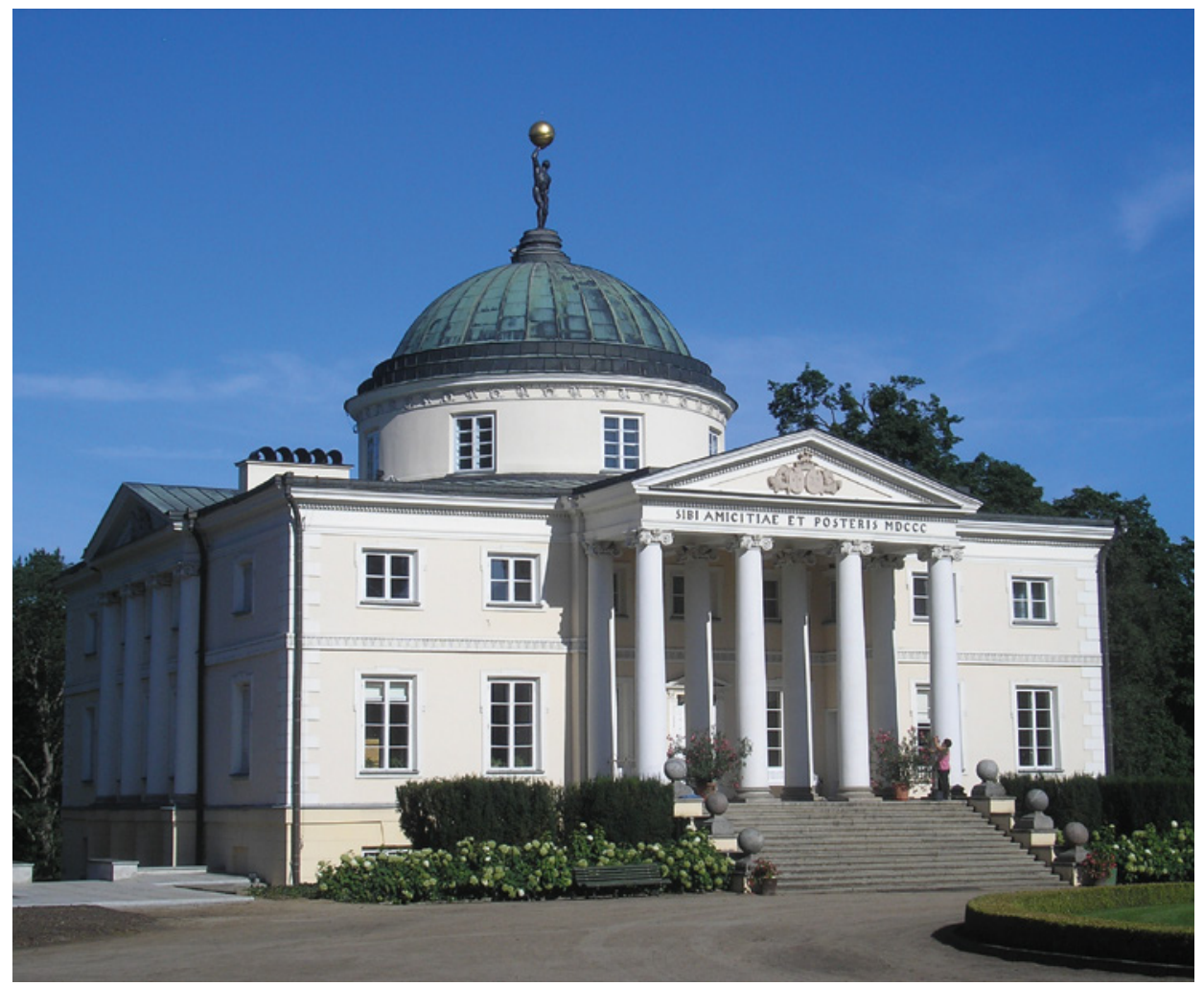

II. 1. Pałac w Lubostroniu

Fot. R. Nowick

słynną sawantkę, przyjaciółkę króla pruskiego Fryderyka II, przechowywane były w pałacu Skórzewskich w Margonińskiej Wsi. Po wzniesieniu przez jej syna Fryderyka hrabiego Skórzewskiego klasycystycznej rezydencji w Lubostroniu (il. 1), wybudowanej w 1800 r. według projektu architekta Stanisława Zawadzkiego, związanego z mecenatem króla Stanisława Augusta Poniatowskiego, część przetransportowano do nowego miejsca ${ }^{5}$ (il. 2). Fundator reprezentacyjnej budowli i założyciel biblioteki w Lubostroniu, w okresie Księstwa Warszawskiego prezes Departamentu Bydgoskiego i poseł na sejm, powiększył zbiory, w skład których wchodziły cenne książki z biblioteki Baltazara Ciecierskiego z Drohiczyna i Ignacego Krasickiego. Zostały one ulokowane $\mathrm{w}$ bibliotece, w specjalnym pomieszczeniu sąsiadującym

powabem umysłu". O formacji intelektualnej Marianny z Ciecierskich Skórzewskiej na podstawie inwentarza jej księgozbioru, „Biblioteka” 2017, nr 21(30), s. 21-42.

5 Inwentariumsverzeichnis zu Schloss Lubostroń, APP L, sygn. 29, k. 59-106; R. Nowicki, Skórzewscy. Właściciele..., s. 54-55. 


\section{VARIA}

\section{Ryszard Nowicki}

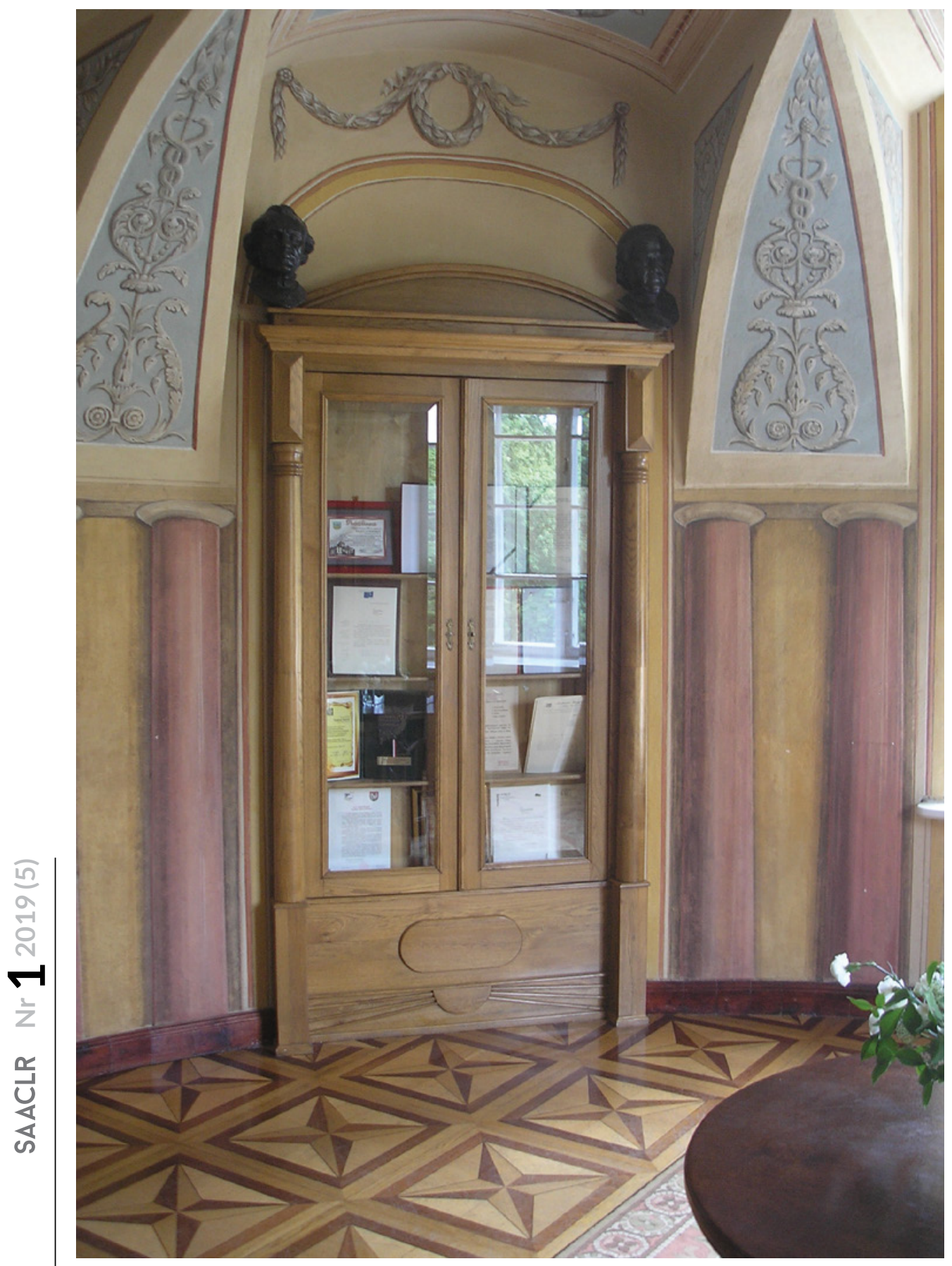

II. 2. Fragment wnętrza dawnej biblioteki pałacowej w Lubostroniu

Fot. R. Nowicki 
z rotundą pałacową. Dalszy rozrost zapewnili jego spadkobiercy, tj. syn Arnold z żoną Melanią Skórzewscy oraz wnuk bibliofil Leon Skórzewski, z którego śmiercią 2 marca 1903 r. wygasła najstarsza linia generalska hrabiowska na Łabiszynie. Rodzice ostatniego właściciela Zygmunta Skórzewskiego, pochodzącego z linii czerniejewskiej, Witold hrabia Skórzewski i Maria z książąt Radziwiłłów Skórzewska, mieli również swój udział w powiększeniu księgozbioru. Pierwsza wojna światowa nie wyrządziła strat zgromadzonej kolekcji. Do 1939 r. w pałacu w Lubostroniu przebywała matka ordynata Maria Skórzewska, która uzupełniała systematycznie zbiory o beletrystykę francuską ${ }^{6}$. Zygmunt Skórzewski wykazywał natomiast zainteresowanie głównie księgozbiorem ordynackim („Obecny właściciel uzupełnia przede wszystkim dział sztuki, nabywając cenne dzieła ilustrowane, zwłaszcza monografie z dziedziny architektury"7). Sytuacja ta wynikała z osobistych zainteresowań IV ordynata, jak również względów praktycznych - w okresie międzywojennym właściciel powiększył czerniejewską rezydencję. Biblioteka w Czerniejewie posiadała katalog, sporządzony w drugiej połowie XIX w. przez Ignacego Polkowskiego, który obejmował ok. 12 tys. dzieł (tj. ok. 1/4 wszystkich tomów) ${ }^{8}$. W wyniku wydarzeń związanych z II wojną światową zbiory uległy znacznemu zniszczeniu oraz rozproszeniu?

Jedynym historykiem literatury, któremu pod koniec XIX w. Leon Skórzewski udostępnił rękopisy biblioteki lubostrońskiej, był Tadeusz Pini ${ }^{10}$. W dwudziestoleciu międzywojennym wgląd do biblioteki miała Bożenna Szulc-Golska. W Lubostroniu przeprowadziła kwerendę w kwietniu 1926 r. ${ }^{11}$ Zwięzłą informację poświęconą księgozbiorowi zamieściła w pracy zbiorowej pod redakcją Stefana Vrtel-Wierczyńskiego Biblioteki wielkopolskie i pomorskie, wydanej w Poznaniu w 1929 r. $^{12}$, w przypadającą setną rocznicę powstania Biblioteki Raczyńskich. Bibliotekarka Biblioteki Uniwersytetu w Poznaniu w archiwum widziała liczne autografy, w tym listy Krasickiego, Garczyńskiego i Fryderyka II. Stwierdziła: „Niestety brak spisu utrudnia orientowanie się w materiale i nie pozwala na jego wyzyskanie naukowe"13.

\footnotetext{
6 B. Szulc-Golska, op. cit., s. 250.

7 Ibidem, s. 239.

8 Ibidem, s. 241.

9 R. Nowicki, Ślady zbiorów hrabiów Skórzewskich w Australii, „Cenne, Bezcenne, Utracone” 2013, nr 1/74-4/77, s. 58-61.

10 Z. Szeląg, Mickiewicz jako korektor „Sonetów wojennych” Stefana Garczyńskiego, „Pamiętnik Literacki” 1963, z. 3, s. 127.

11 R. Nowicki, „Księga Pamiątkowa” pałacu w Lubostroniu, „Promocje Kujawsko-Pomorskie” 2007, nr 1-6, S. 8.

12 B. Szulc-Golska, op. cit., s. 250-251.

13 Ibidem, s. 251. Nie odnaleziono, jak dotąd, żadnej ikonografii przedstawiającej wnętrze biblioteki pałacowej w Lubostroniu.
} 
Istnienie księgi inwentarzowej biblioteki lubostrońskiej nie zostało odnotowane w literaturze przedmiotu. Na temat katalogu nie znajdziemy żadnej wzmianki, ponieważ nie został sporządzony. Zachowana księga jest przechowywana w Archiwum OO. Franciszkanów Prowincji Matki Bożej Niepokalanej w Warsza$w^{1}{ }^{14}$. Pomimo podjętych prób nie zdołano prześledzić jej drogi do Archiwum. W notatce przekazania rękopisu z 2 sierpnia 2017 r. podano, że jest to rejestr alfabetyczny pozycji książkowych z bliżej nieokreślonej biblioteki ${ }^{15}$. Czy dotyczy księgozbioru w Lubostroniu?

Księga inwentarzowa nie ma tytułu. Na kartach odciśnięto dwa czerwone znaki proweniencyjne okrągłą pieczęcią. W otoku widnieje napis LUBOSTROŃ, powyżej skrzyżowane dwie litery LS, nad którymi znajduje się dziewięciopałkowa korona hrabiowska. Informacje oraz monogram wskazują bezsprzecznie na właściciela, tj. Leona Skórzewskiego i Lubostroń. Jednak wątpliwości nadal istniały z powodu przekreślenia znaków proweniencyjnych (il. 3). Powróciło pytanie zasadnicze: czy inwentarz dotyczy nieistniejącego już księgozbioru Skórzewskich, czy może innego zasobu? Mógł przecież trafić do biblioteki lubostrońskiej, a jej właściciel włączył księgę do zbioru, odciskając własny znak. By uzyskać odpowiedź na nurtujący problem, dokonano analizy inwentarza i jego zawartości. Ustalono czas powstania księgi na wiek XIX. Stan zachowania jest dobry. Pozbawione paginacji karty w szerokie linie, o wymiarach $38,5 \mathrm{~cm} \times 24,5 \mathrm{~cm}$, są szyte. Oprawa twarda pokryta jest ciemnobrązowym płótnem z widocznymi śladami częściowego zalania (il. 4). Wyklejki są koloru zielonego, natomiast kapitałka wydziergana jest nićmi czerwonymi. Spis został sporządzony w układzie alfabetycznym. Korzystanie z inwentarza ułatwiały drukowane duże litery: od A do Z (ogółem 24 litery), naklejone na przyciętym z prawej strony marginesie o szerokości ok. $1,5 \mathrm{~cm}$ (il. 5). Jedna karta została odcięta. Pozostał po niej pas o szerokości od ok. $3 \mathrm{~cm}$ do ok. $2 \mathrm{~cm}$. Nie wynikało to z aktu wandalizmu, lecz, jak przypuszczam, pomyłki związanej z pierwotnym zakłóceniem układu alfabetycznego. Świadczy o tym zachowany fragment papieru zawierający urwany mechanicznie zapis: Rako. Kolejną kartę rozpoczyna nazwisko Raczyński, a na następnej odnotowano autora wcześniej zapewne zapisanego i usuniętego, tj. Rakowicki. Pod literą Z została wydarta jedna karta, przypuszczalnie pusta. Wpisy zostały dokonane różnymi duktami pisma, głównie piórem i sporadycznie ołówkiem. Ogółem księga liczy 379 kart, w tym 278 zapisanych, a 101 jest pustych. Na stronicach widnieje od jednego do kilkudziesięciu wpisów. Wypełnione notami w $100 \%$ karty należą do rzadkości. Spis inwentarzowy rozpoczyna Abecadnik polski, tj. elementarz wydany w Wilnie w 1845 r., a kończą przekreślone

14 Rękopis „Rejestru alfabetycznego" pozycji książkowych, Archiwum OO. Franciszkanów Prowincji Matki Bożej Niepokalanej w Warszawie [bez sygn.].

15 Notatka z przekazania do Archiwum Franciszkanów rękopisu „Rejestru alfabetycznego” pozycji książkowych, [Warszawa], 2 VIII 2017 r., Archiwum OO. Franciszkanów Prowincji Matki Bożej Niepokalanej w Warszawie [bez sygn.]. 
Księga inwentarzowa księgozbioru hrabiów Skórzewskich... Inventory Book of the Skórzewski Counts' Lubostroń Library...

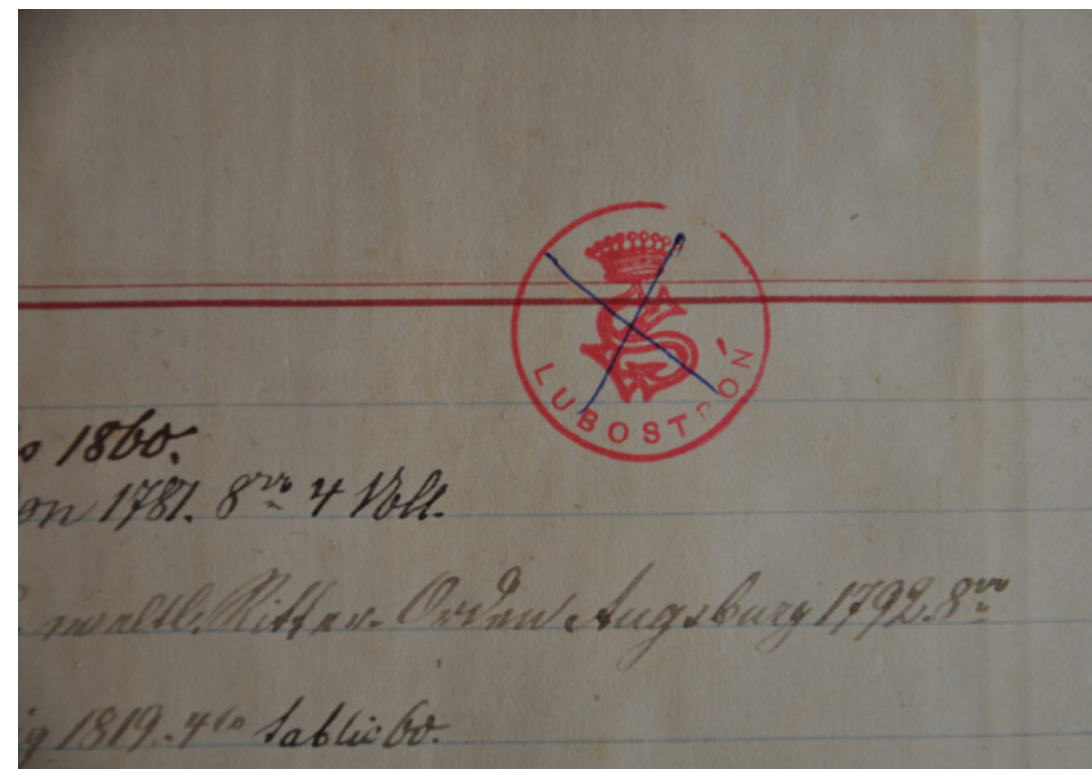

II. 3. Znak proweniencyjny Leona Skórzewskiego

Fot. R. Nowicki

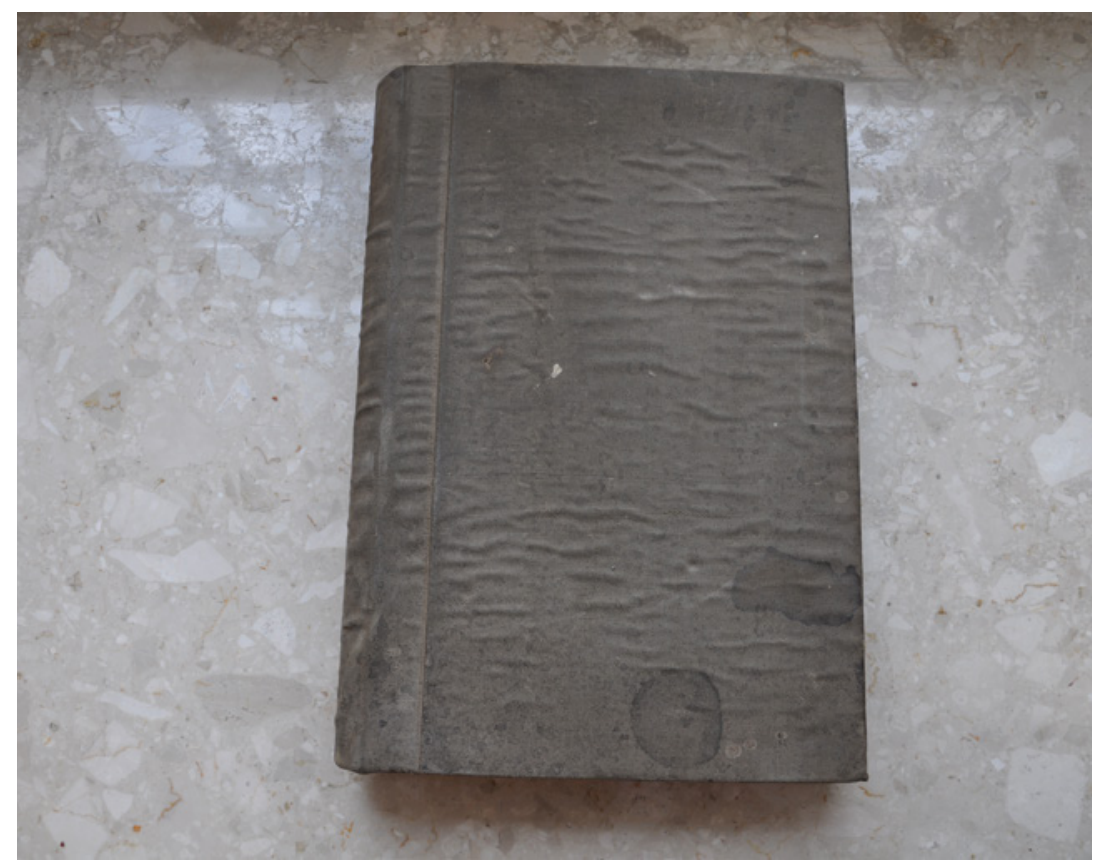

II. 4. Oprawa księgi inwentarzowej

Fot. R. Nowicki 


\section{VARIA}

Ryszard Nowicki

cztery pozycje zapisane ołówkiem pod literą Z („Zjednoczenie” pismo emigracyjne z roku 1841 i 1842; „Zabawy Przyjemne i Pożyteczne” z lat 1770-1776; wydawane przez wybitnego komika Alojzego Żółkowskiego trzy tomy pisma satyrycznego „Momus”, wyd. II, Kraków 1836 oraz „Zbratnienie”, pismo poświęcone sprawie polskiej, Paryż 1847) ${ }^{16}$. Z inwentarza wynika, że biblioteka pod koniec lat 80. XIX w. liczyła ogółem kilka tysięcy tytułów w kilkunastu tysiącach tomach.

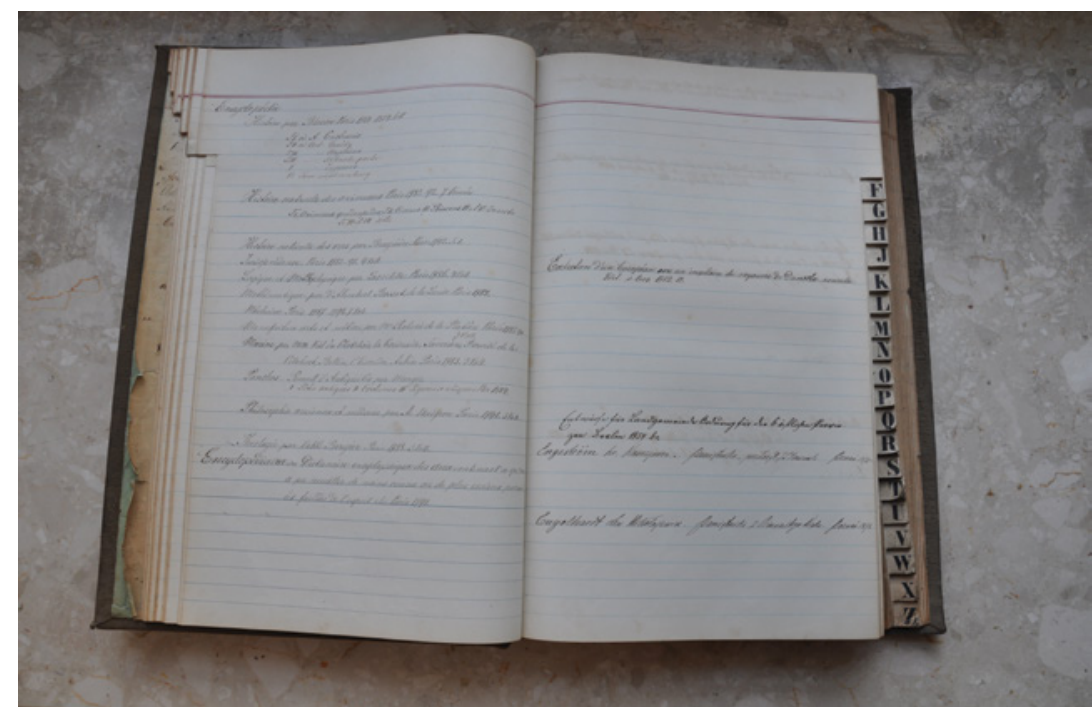

II. 5. Wpisy w inwentarzu

Fot. R. Nowicki

Kto i kiedy zapoczątkował spis pozycji piśmienniczych znajdujących się w bibliotece pałacowej? Przypuszczam, że inwentarz został sporządzony przez ks. Ignacego Polkowskiego. „Były konserwator i opiekun zbiorów lubostrońskich”17, jak nazwał bibliofila Władysław Bartynowski ${ }^{18}$ w liście do Leona Skórzewskiego, korzystał z gościny Skórzewskich w Czerniejewie i Lubostroniu w latach 1866-1877. Archiwariusz i historyk w przedmowie do Historii majętności łabiszyńskiej, wydanej nakładem Biblioteki Lubostrońskiej w Poznaniu w 1876 r., wspomniał o porządkowaniu naukowych zbiorów lubostrońskich i miejscowego archiwum, liczącego

16 Kolejność podano według zapisu inwentarza. Powyższe tytuły zostały odnotowane wcześniej, dlatego przypuszczalnie zostały przekreślone. Innych pozycji pod literą Z nie zapisano.

17 Kopiały listów Władysława Martynowskiego do różnych osób z lat 1887-1890, Zakład Narodowy im. Ossolińskich we Wrocławiu (dalej: ZNO), sygn. 12533/II, k. 329 - Władysław Bartynowski do Leona Skórzewskiego, Kraków, 15 marca 1889 r.

18 Władysław Bartynowski zainteresowany był numizmatami hrabiego. W Krakowie korzystał z przesłanych z Lubostronia czterech katalogów, w tym uważanego za główny, oprawionego i zatytułowanego Książka wydatków na Monety i Medale polskie. 
ponad 7000 dokumentów i autografów ${ }^{19}$. W pałacu znalazł dogodne warunki do prowadzenia własnych badań naukowych, w tym dotyczących życia i działalności Mikołaja Kopernika. Utrzymywał kontakt z mieszkającym w Dreźnie Józefem Ignacym Kraszewskim, któremu w korespondencji wspominał o lubostrońskiej bibliotece ${ }^{20}$. Czynił także starania o zakup części księgozbioru Józefa Ignacego Kraszewskiego do Lubostronia. W bezimiennym artykule, autorstwa zapewne Ignacego Polkowskiego, ogłoszonym w 1878 r. w warszawskim „Tygodniku llustrowanym", podano:

Wewnątrz pałacu mieszczą się: wspaniała stiukowana sala, przez wszystkie piętra, oświetlona z góry pod kopułą, arcyszacowna, jedna z pierwszych w kraju biblioteka, oraz pamiątkowe historyczne zbiory, staraniem i kosztem teraźniejszego dziedzica hr. Leona Skórzewskiego, umiejętnie utrzymywane, porządkowane i wzbogacane ${ }^{21}$.

Duchowny katalogował podczas pobytu w Czerniejewie księgozbiór II ordynata na Radomicach-Czerniejewie Zygmunta Skórzewskiego. Mógł zatem, celem uporządkowania zbioru, założyć inwentarz w Lubostroniu.

Księgę sporządzono w celach ewidencyjno-kontrolnych. Świadczą o tym występujące informacje o brakach poszczególnych tomów, roczników, numerów czasopism. Ze spisu wynika, że zgromadzony materiał w bibliotece nie miał nadanych sygnatur. Książki zatem ustawione były według układu alfabetycznego. W inwentarzu odnotowano nazwisko autora, jego imię, tytuł, miejsce i rok wydania, liczbę tomów. Występują tam informacje o wydawcy, kolejnych wydaniach, przedrukach, tłumaczeniach, seriach wydawniczych, formacie ${ }^{22}$, ale są też braki polegające na zapisaniu przykładowo jedynie fragmentu tytułu bez podania dodatkowych wiadomości. Pojawiają się także krótkie komentarze, skreślenia oraz uzupełnienia informacji. Księga zawiera wykaz pozycji wchodzących w skład zbiorów bibliotecznych. Odnotowano przede wszystkim druki zwarte i ciągłe, rzadko występują rękopisy, a zwłaszcza inkunabuły. Stare druki natomiast są licznie reprezentowane. Najwięcej figuruje dzieł wydanych w języku polskim w XIX w. Widnieją także i w innych językach, np. francuskim, niemieckim, po łacinie. Drukowane były w różnych oficynach krajowych i zagranicznych, m.in. we Francji, Niemczech, Włoszech, Rosji czy Anglii. Wpisów dokonywano w zasadzie do końca 1889 r. Tylko jedną pozycję zapisano wydaną w 1890 r. Późniejszych materiałów, które bez wątpienia trafiły do biblioteki za sprawą znawcy i miłośnika książek Leona Skórzewskiego oraz kolejnych mieszkańców pałacu, już nie ujęto. Dlaczego nagle zaprzestano dokonywać zapisów? Nie wynikało to z braku miejsca w inwentarzu, o czym świadczą puste

\footnotetext{
19 I. Polkowski, Historia majętności łabiszyńskiej, Biblioteka Lubostrońska w Poznaniu, Poznań 1876, s. 3.

20 R. Nowicki, Listy Ignacego Polkowskiego do Józefa lgnacego Kraszewskiego z lat 1866-1877, „Ziemia Kujawska" 2005, t. 18, s. 131-161.

21 [I. Polkowski], Łabiszyn w W. Ks. Poznańskim, „Tygodnik llustrowany” 1878, t. VI, nr 143, s. 189.

22 Odnotowanie formatu może wskazywać, że część książek ustawiono według wielkości.
} 


\section{VARIA}

Ryszard Nowicki

karty i wolne miejsca do odnotowywania kolejnych nabytków. Czy powstał kolejny inwentarz, a dotychczas używany uznano za nieaktualny i przestano z niego korzystać? Czy w 1890 r. wprowadzono nowy sposób porządkowania zbiorów? To by mogło wyjaśnić przekreślenie dwóch znaków własnościowych. Ale fakt ich unieważnienia mógł nastąpić znacznie później, tj. również po II wojnie światowej. Być może brak dalszych zapisów jest związany ze śmiercią w Krakowie 27 sierpnia 1888 r. Ignacego Polkowskiego, który wcześniej, jak wspomniano, wykonywał prace porządkowe w Lubostroniu i prawdopodobnie założył księgę inwentarzową. Książkołap w 1877 r. opuścił rezydencję ufundowaną przez Fryderyka Skórzewskiego i Wielkopolskę ${ }^{23}$. Utrzymy wał kontakt listowny z Leonem Skórzewskim i nadal interesował się zbiorami lubostrońskimi. Niektóre druki i rękopisy, a zwłaszcza monety, wypożyczył na wystawę do Krakowa. Po zgonie Ignacego Polkowskiego hrabia zabiegał o ich zwrot. Faktem jest, że kilkanaście miesięcy po jego śmierci zaniechano dalszych wpisów.

W dwudziestoleciu międzywojennym brak katalogu utrudniał odnalezienie poszukiwanych materiałów i dostęp do zbiorów. Zainteresowanie dotyczyło zwłaszcza korespondencji Adama Mickiewicza lub poprawek dokonanych przez wieszcza na rękopisach Stefana Garczyńskiego, poety doby romantyzmu i przyjaciela wieszcza. Autor poematu Wacława dzieje po wczesnej śmierci rodziców był wychowywany w Lubostroniu przez Fryderyka Skórzewskiego i jego żonę Antoninę z Garczyńskich Skórzewską (ciotkę chłopca). Po zgonie pisarza (zmarł 20 września 1833 r. w Awinionie) Arnold Skórzewski pozyskał liczne rękopisy kuzyna, w tym z naniesionymi poprawkami przez Adama Mickiewicza ${ }^{24}$. W drugiej połowie XIX W. Klemens Kantecki skierował list do Leona Skórzewskiego, syna Arnolda Skórzewskiego, w którym prosił hrabiego „o łaskawe doniesienie m[u] wszelkich wiadomości z czasów pobytu wieszcza w Lubostroniu, przesłanie kopii listów itp."25. Adam Mickiewicz nigdy nie przebywał w tym miejscu, które bez wątpienia dobrze znał z opowiadań Stefana Garczyńskiego. Po odzyskaniu przez Polskę niepodległości dyrektor Zakładu Narodowego im. Ossolińskich we Lwowie Ludwik Bernacki pragnął wyzyskać naukowo cenny materiał źródłowy. Zygmunt Skórzewski 16 listopada 1924 r. wyraził pisemną zgodę na udostępnienie zainteresowanemu zbiorów. Pomimo bogatej korespondencji z ordynatem, trwającej do 1929 r., Ludwikowi Bernackiemu nie udało się przeprowadzić kwerendy ${ }^{26}$. Tego roku hrabia odpisał Stanisławowi Pigoniowi: „Niestety biblioteka, jak i archiwum nie są uporządkowa-

\footnotetext{
23 Został wydalony przez władze pruskie w wyniku wytoczonego procesu, głównie z powodu opublikowania w 1873 r. druku pt. Czterowiekowy jubileusz Mikołaja Kopernika w Toruniu.

24 Z. Szeląg, Los archiwum Skórzewskich, „Ruch Literacki”, 1965, R. VI, z. 2, s. 71-72.

25 Listy literatów i uczonych polskich, głównie XIX wieku, Biblioteka Narodowa w Warszawie (dalej: BN), sygn. 2674, k. 112 - Klemens Kantecki do Leona Skórzewskiego, Poznań, 24 VIII 1875 r.

26 Papiery Ludwika Bernackiego, ZNO, sygn. 7049/II, k. 21-51.
} 
ne, co niezmiernie poszukiwania utrudnia"27. Kilka lat później, 25 marca 1936 r., Zygmunt Skórzewski skierował pismo do dyrektora Biblioteki Raczyńskich w Poznaniu Andrzeja Wojtkowskiego:

W odpowiedzi na list z dnia 11 b.m. donoszę uprzejmie, że rękopisu Garczyńskiego w Czerniejewie do tej pory nie spotkałem, może znajduje się w Lubostroniu, co jest więcej prawdopodobne, ponieważ był spokrewniony z Hr. Fryderykową Skórzewską. Temi dniami wybieram się do Lubostronia i postaram się odszukać wspomniany rękopis, o ile go znalezę, każę natychmiast odnośną kartkę z autografem Mickiewicza sfotografować, względnie prześlę rękopis do Poznania pod adresem biblioteki celem wcielenia go do mojego depozytu"28.

Z milczenia źródeł można przypuszczać, że materiału nie odszukał i nie przekazał do Biblioteki Raczyńskich ${ }^{29}$.

Powróćmy do informacji Bożenny Szulc-Golskiej, która wymieniła czasopisma zagraniczne poświęcone sprawie polskiej przechowywane w Lubostroniu, w tym "Orzeł Biały” ukazujący się w Brukseli oraz „Dziennik Narodowy” publikowany w Paryżu ${ }^{30}$. Dwutygodnik "Orzeł Biały” wychodził w latach 1839-1848, według inwentarza w bibliotece przechowywano roczniki 1839-1841. Tygodnik „Dziennik Narodowy" drukowano w stolicy Francji w latach 1841-1848. Z wpisów wynika, że zgromadzono komplet roczników. Bogato reprezentowane w księdze są: literatura powstaniowa, emigracyjna, a także pierwodruki autorów polskich XIX w. i beletrystyka francuska. Jest to zgodne z wiadomością podaną przez Bożennę Szulc-Golską. Jednak nadal brakowało niezbitego dowodu pozwalającego bezsprzecznie stwierdzić, że jest to inwentarz księgozbioru lubostrońskiego. W celu rozwiązania problemu postanowiono odszukać pozycję odnotowaną w księdze, która przetrwała i jest przechowywana współcześnie w jednej z bibliotek. Zwrócono uwagę zwłaszcza na podany w inwentarzu rękopis Deductio Genealogiae Illustrissimae Prosapiae Gembicianae opatrzony krótkim komentarzem: „Prześliczny Manuskrypt na pergaminie 127 kart in folio". Genealogia Gembickich ${ }^{31}$, z zachowanymi trzema znakami proweniencyjnymi Leona Skórzewskiego, identycznymi z odciśniętymi w inwentarzu, jest przechowywana w Bibliotece Uniwersyteckiej w Poznaniu - sygnatura rękopisu 683 IV. Tak więc przetrwał niepodważalny dowód, który z całą pewnością pozwala stwierdzić, że zachowany inwentarz dotyczy księgozbioru biblioteki w Lubostroniu.

\footnotetext{
27 Korespondencja Stanisława Pigonia, Biblioteka Jagiellońska w Krakowie, sygn. 10822 III, k. 145 - List Zygmunta Skórzewskiego do Stanisława Pigonia, [Czerniejewo,] 27 X [19]29 r.

28 Korespondencja Wacława Borowego dotyczaca wydania dzieł Mickiewicza, BN, sygn. III/7507, k. 11 - List Zygmunta Skórzewskiego do Andrzeja Wojtkowskiego, Czerniejewo, 25 III 1936 r.

29 Porządkowaniem lubostrońskich zbiorów bibliotecznych i archiwum miała się zająć studentka historii Uniwersytetu w Poznaniu Barbara Górska, córka Franciszka Górskiego (pełnomocnika Skórzewskich). Wybuch II wojny światowej uniemożliwił realizację planu.

30 B. Szulc-Golska, op. cit., s. 250.

31 Spokrewniona z Gembickimi była Marianna z Ciecierskich, żona gen. Franciszka Skórzewskiego. Dobra łabiszyńskie z Łabiszynem, przed Skórzewskimi, stanowiły własność Gembickich.
} 


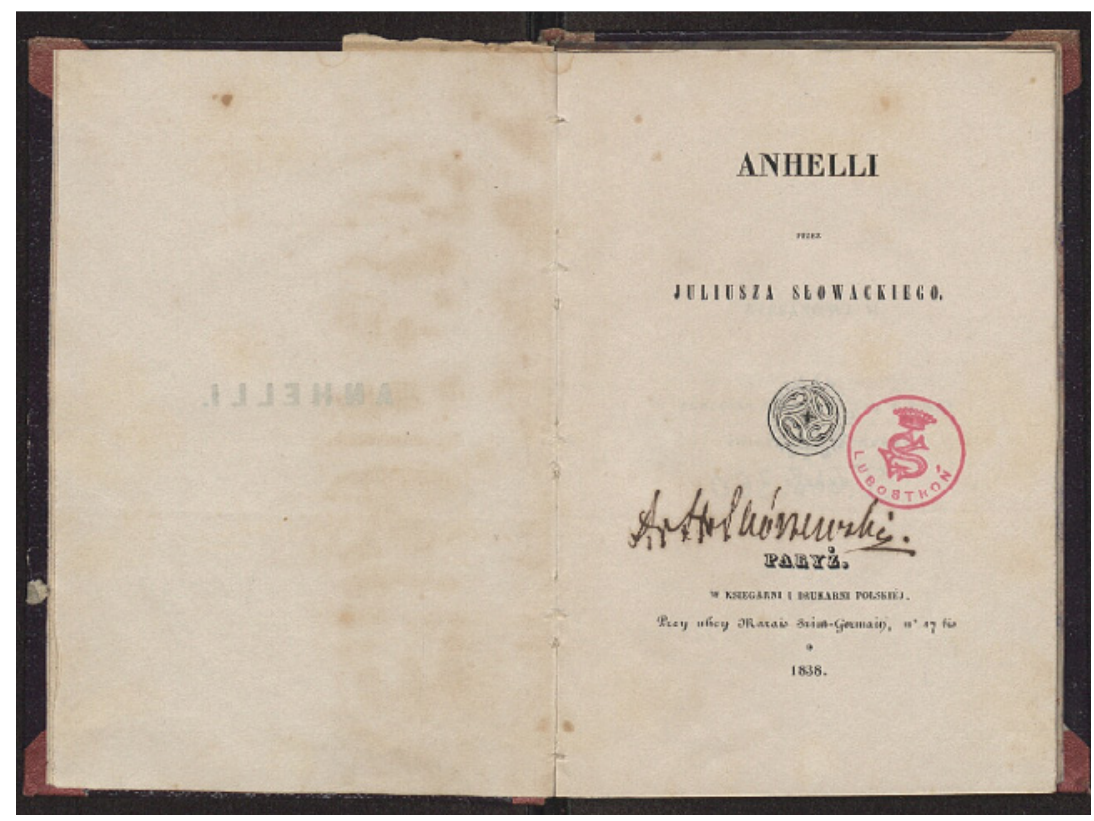

II. 6. Znaki własnościowe Skórzewskich na poemacie Juliusza Słowackiego Anhelli Źródło: J. Słowacki, Anhelli, Paryż 1838 r., Biblioteka Narodowa w Warszawie, sygn. I 648.360 Cim. (fot. Polona uid 97674128, domena publiczna)

Rozproszone egzemplarze ze zbioru lubostrońskiego w wyniku wydarzeń związanych z II wojną światową i tuż po niej występują w różnych bibliotekach krajowych i zagranicznych. Przykładowo w poznańskiej Bibliotece Uniwersyteckiej znajdują się inkunabuły oraz stare druki z XVI w., w tym z oficyn krakowskich: Jana Hallera, Floriana Unglera, Jakuba Siebeneichera czy Łazarza Andrysowicza, a także z zagranicznych ośrodków wydawniczych, tj. Bazylei, Lyonu czy Strasburga. Przetrwały niektóre rękopisy, traktaty filozoficzne, modlitewniki, przepisy kulinarne, lekarskie, gospodarcze i inne. W Bibliotece Raczyńskich w Poznaniu zachowała się skromna liczba materiałów z dawnego depozytu Zygmunta Skórzewskiego. Książki z księgozbioru pałacowego w Lubostroniu można m.in. odszukać w Bibliotece Narodowej w Warszawie, np. poemat Juliusza Słowackiego Anhelli, wydany w Paryżu w 1838 r., opatrzony autografem Arnolda Skórzewskiego i znakiem proweniencyjnym Leona Skórzewskiego (il. 6).

Historyczny inwentarz dowodzi zgromadzenia dzieł z różnych dziedzin, np. historii, prawa, sztuki, teologii, nauk ścisłych, geografii, przyrody, filozofii, literatury polskiej i obcej. W zbiorze lubostrońskim znajdowały się liczne wartościowe pozycje, w tym m.in. pierwsze wydania polskich XIX-wiecznych klasyków: Adama Mickiewicza, Juliusza Słowackiego, Józefa Ignacego Kraszewskiego. Bogato reprezentowane były druki zwarte i ciągłe wydane na emigracji oraz w kraju. Do ich pozyskania przyczynił się szczególnie uczestnik powstania listopadowego Arnold 
Księga inwentarzowa księgozbioru hrabiów Skórzewskich... Inventory Book of the Skórzewski Counts' Lubostroń Library...

Skórzewski, który wspólnie z żoną wiele lat spędził w Paryżu. Materiał piśmienniczy bez wątpienia gromadzono nie z chęci posiadania, lecz wynikał z osobistych zainteresowań właścicieli, o czym świadczy zachowany cenny inwentarz.

\section{Bibliografia}

Bieńkowska B. (red.), Informator o stratach bibliotek i księgozbiorów domowych na terytoriach polskich okupowanych w latach 1939-1945 (bez Ziem Wschodnich), Ministerstwo Kultury i Dziedzictwa Narodowego, Poznań 2000.

Bieńkowska B., Kowalski W., Łaskarzewska H., Paszkiewicz U., Waligórski S., Straty bibliotek w czasie Il wojny światowej w granicach Polski z 1945 roku. Wstępny raport o stanie wiedzy. Część I. Analiza, Część II. Tablice, Reklama Wojciech Wójcicki, Warszawa 1994.

Chwalewik E., Zbiory polskie, t. 1, Wydawnictwo J. Mortkowicza, Towarzystwo Wydawnicze w Warszawie, Warszawa 1926.

Inventarium des Nachlass der 18 XI 1774 in Berlin verstorbenen Fr. Grafin von Skórzewska, Archiwum Państwowe Poznań, Akta majątkowe i rodzinne Skórzewskich - Lubostroń, sygn. $27, \mathrm{k} .137-168$

Inwentariumsverzeichnis zu Schloss Lubostroń, Akta majątkowe i rodzinne Skórzewskich - Lubostroń, sygn. 29, k. 59-106.

Kłudkiewicz K., „Czarować chciała tylko powabem umysłu”. O formacji intelektualnej Marianny z Ciecierskich Skórzewskiej na podstawie inwentarza jej księgozbioru, „Biblioteka” 2017, $\mathrm{nr} 21(30)$.

Kopiały listów Władysława Martynowskiego do różnych osób z lat 1887-1890, Zakład Narodowy im. Ossolińskich we Wrocławiu, sygn. 12533/II, k. 329 - Władysław Bartynowski do Leona Skórzewskiego, Kraków, 15 III 1889 r.

Korespondencja Stanisława Pigonia, Biblioteka Jagiellońska w Krakowie, sygn. 10822 III, k. 145 - List Zygmunta Skórzewskiego do Stanisława Pigonia, [Czerniejewo,] 27 X [19]29 r.

Korespondencja Wacława Borowego dotycząca wydania dzieł Mickiewicza, Biblioteka Narodowa w Warszawie, sygn. III/7507, k. 11 - List Zygmunta Skórzewskiego do Andrzeja Wojtkowskiego, Czerniejewo, 25 III 1936 r.

Kosmanowa B., Biblioteki polskie w Wielkim Księstwie Poznańskim, Wydawnictwo Naukowe Uniwersytetu im. Adama Mickiewicza, Poznań 1982.

Listy literatów i uczonych polskich, głównie XIX wieku, Biblioteka Narodowa w Warszawie, sygn. 2674, k. 112 - Klemens Kantecki do Leona Skórzewskiego, Poznań, 24 VIII 1875 r.

Notatka z przekazania do Archiwum Franciszkanów rękopisu „Rejestru alfabetycznego” pozycji książkowych, [Warszawa], 2 VIII 2017 r., Archiwum OO. Franciszkanów Prowincji Matki Bożej Niepokalanej w Warszawie [bez sygn.].

Nowicki R., Fragment biblioteki rodowej i ordynackiej Skórzewskich w Bibliotece Raczyńskich, „Biblioteka” 2004, nr 8(17).

Nowicki R., „Księga Pamiątkowa” pałacu w Lubostroniu, „Promocje Kujawsko-Pomorskie” 2007, nr 1-6.

Nowicki R., Listy lgnacego Polkowskiego do Józefa Ignacego Kraszewskiego z lat 1866-1877, „Ziemia Kujawska” 2005, t. 18. 


\section{VARIA}

Ryszard Nowicki

Nowicki R., Skórzewscy. Właściciele dóbr łabiszyńskich. Rola w życiu społeczno-politycznym wielkopolskiego ziemiaństwa, Wydawnictwo Adam Marszałek, Toruń 2002.

Nowicki R., Ślady zbiorów hrabiów Skórzewskich w Australii, „Cenne, Bezcenne, Utracone” 2013, nr 1/74-4/77.

Papiery Ludwika Bernackiego, Zakład Narodowy im. Ossolińskich we Wrocławiu, sygn. 7049/II, k. 21-51.

Polkowski I., Historia majętności łabiszyńskiej, Biblioteka Lubostrońska w Poznaniu, Poznań 1876.

[Polkowski I.], Łabiszyn w W. Ks. Poznańskim, „Tygodnik Ilustrowany” 1878, t. VI, nr 143.

Rękopis „Rejestru alfabetycznego” pozycji książkowych, Archiwum OO. Franciszkanów Prowincji Matki Bożej Niepokalanej w Warszawie [bez sygn.].

Szeląg Z., Los archiwum Skórzewskich, „Ruch Literacki”, 1965, R. VI, z. 2.

Szeląg Z., Mickiewicz jako korektor „Sonetów wojennych” Stefana Garczyńskiego, „Pamiętnik Literacki" 1963, z. 3.

Szulc-Golska B., Wielkopolskie biblioteki prywatne, w: S. Wierczyński (red.), Biblioteki wielkopolskie i pomorskie, Komitet Organizacyjny IV Zjazdu Bibliofilów i II Zjazdu Bibliotekarzy Polskich, Poznań 1929.

Wojtkowski A., „Habent sua fata...”. Jak rośnie i bogaci się Biblioteka Raczyńskich, „Kurier Poznański" 1932, R. 27, nr 410. 